\title{
RESEARCH REGARDING THE EFFECT OF LEPTIN UPON THE RATIO OF CERTAIN LYMPHOCYTE POPULATIONS IN RAT
}

\author{
MARIAN GHIȚ $\breve{~}^{1}$, RĂZVAN BOTEZATU ${ }^{2}$, CRISTIN COMAN ${ }^{3}$, VLAD VUȚA $^{4 *}$, GABRIEL \\ GÂJÂILA ${ }^{1}$, ALINA CRENGUȚA NICOLAE ${ }^{5}$, CRISTINA MANUELA DRĂGOI ${ }^{5}$, GABRIEL \\ COTOR $^{1}$
}

\author{
${ }^{1}$ University of Agronomic Sciences and Veterinary Medicine, 59 Mărăşti Boulevard, 011464, Bucharest, Romania \\ ${ }^{2}$ Centrovet Veterinary Center, 52-54 Pascal Aristide Street, 031443, Bucharest, Romania \\ 3 “Cantacuzino" National Medico-Military for Research and Development Institute, 103 Splaiul Independenței, 050096, \\ Bucharest, Romania \\ ${ }^{4}$ Institute for Diagnosis and Animal Health, 63 Dr. Staicovici Street, 050557, Bucharest, Romania \\ 5 "Carol Davila" University of Medicine and Pharmacy, Faculty of Pharmacy, Biochemistry Department, 020956, Bucharest, \\ Romania
}

*corresponding author: vladvuta@yahoo.com

\begin{abstract}
The aim of the present research was to investigate the effects of exogenous leptin on the ratio of T and B lymphocytes populations in order to assess the theory regarding the implication of this hormone in the stimulation of the immune system. Rats included in the experimental group have been injected with leptin for 14 days. Blood samples from the experimental and control group were withdrawn on the $14^{\text {th }}$ and $21^{\text {st }}$ day after the leptin administration. Further on there were assessed different lymphocyte populations using the direct immunofluorescence technique: $\mathrm{TCD}_{3}, \mathrm{TCD}_{4}, \mathrm{TCD} 8$, and $\mathrm{BCD}_{45}$. The results revealed that after 14 days from the last inoculation, leptin induces stimulant effects on all the assessed lymphocyte populations. These effects were statistically insignificant $(p>0.05)$. Nevertheless, on the $21^{\text {st }}$ day after the last inoculation, the stimulant effects were statistically significant ( $\mathrm{p}<0.01$ ) for the lymphocytes: $\mathrm{TCD}_{3}$ (with $47.21 \%$ ), $\mathrm{TCD}_{4}$ (with $39.68 \%$ ) and $\mathrm{TCD}_{8}($ with $50.43 \%$ ). In addition, on the $21^{\text {st }}$ day after the last inoculation, we found also a statistically significant stimulatory effect ( $p<$ 0.01) upon $\mathrm{BCD}_{45}$ lymphocytes (with $40.83 \%$ ). However, this effect was weaker compared to the one manifested upon $\mathrm{T}$ lymphocytes because the responsiveness of B lymphocytes to leptin's action was proved to be lower than the one for $\mathrm{T}$ lymphocytes. Based on our results, we can assert that leptin induces an amplification of the effectors proportion involved in the cellular mediated immune response.
\end{abstract}

\section{Rezumat}

Scopul studiului a fost de a investiga efectele leptinei exogene asupra raportului populațiilor de limfocite T și B pentru a verifica teoria cu privire la implicarea acestui hormon în stimularea sistemului imunitar. Cercetarea s-a realizat pe un grup experimental de șobolani injectați cu leptină timp de 14 zile. S-au prelevat probe de sânge de la grupul experimental și cel de control, căruia nu i s-a administrat acest hormon, în a 14-a și a 21-a zi după administrarea leptinei. S-a evaluat astfel proporția următoarelor populații de limfocite, folosind tehnica imunofluorescenței directe: $\mathrm{TCD}_{3}, \mathrm{TCD}_{4}, \mathrm{TCD} 8$ și $\mathrm{BCD}_{45}$. Rezultatele obținute arată că după 14 zile de la ultima inoculare, leptina induce efecte stimulatoare asupra tuturor populațiilor de limfocite testate. Aceste efecte au fost statistic nesemnificative ( $p>0,05$ ). În contrast, în a 21-a zi după ultima inoculare, efectele stimulatoare au fost statistic semnificative $(\mathrm{p}<0,01)$ pentru următoarele tipuri de limfocite: $\mathrm{TCD}_{3}(\mathrm{cu} 47,21 \%), \mathrm{TCD}_{4}(\mathrm{cu} 39,68 \%)$ și $\mathrm{TCD}_{8}(\mathrm{cu}$ 50,43\%). În ceea ce privește efectul stimulator menționat, raportul dintre subpopulațiile TCD 4 și TCD8 nu a suferit modificări. În plus, în a 21-a zi după ultima inoculare s-a determinat și un efect stimulator statistic semnificativ $(p<0,01)$ asupra limfocitelor $\mathrm{BCD}_{45}$ (cu 40,83\%). Cu toate acestea, efectul a fost mai slab în comparație cu cel care s-a manifestat asupra limfocitelor T, deoarece reacția limfocitelor B la acțiunea leptinei s-a dovedit a fi mai redusă decât cea înregistrată asupra limfocitelor T. Pe baza rezultatelor obținute, putem afirma că leptina induce o amplificare a proporției efectorilor implicați în răspunsul imun mediat celular.

Keywords: leptin, lymphocytes, immune system, rat

\section{Introduction}

The leptin is a relatively recent discovered and described tissue hormone so that the secretion mechanisms and its roles are not totally elucidated. It is known that the leptin's secretion is reduced in patients with anorexia and abundant in obese patients [2], but also that physical exercises decrease the blood level of leptin [14]. It seems that leptin provides a key link between the nutritional status of the body and the involvement of $\mathrm{T}$ cells in the inflammatory response [6], in malnutrition decreased $\mathrm{T}$ cell function being associated with decreased leptin levels [4]. Moreover, it seems that leptin is involved in 
maintaining the lymphopoiesis and myelopoiesis [3] and it induces an allergic inflammatory response by stimulating the diapedesis and encouraging tissue migration of eosinophils [19].

The issue of the functional correlation between leptin and the immune system's elements was not debated based on systematic researches that can elucidate this problem, so far.

In the last few years, different researchers have revealed that leptin has effects not only on neuro-endocrine and metabolic functions, but also on the immune system [1]. Some of these results have demonstrated that the absence of leptin is responsible for the appearance of immunosuppression and thymic atrophy. These changes have been observed in acute starvation and malnutrition [8]. Moreover, it stimulates the expression of adhesion molecules and increases the cytotoxic capacity of NK cells and of $\mathrm{IL}_{2}[10]$. After inducing the experimental malnutrition, the blood level of leptin decreased, due to the reduction of adipose tissue, and it caused also deficiencies of the immune system [20]. Consequently, leptin seems to be an important factor for the organism well-functioning because it adjusts the practical correlation between the nutrition state, energy metabolism and immune function $[14,17,18]$.

Regarding the innate immunity, it was demonstrated that leptin modulates the activity of neutrophils by increasing the chemotaxis and producing oxygen free radicals [12]. In rat, during the neonatal period, leptin present in breast milk has immunomodulatory properties [9], playing an important role in the regulation of the immune response [7].

Leptin seems to directly activate neutrophils in mice, but regarding the human organism, leptin seems to be mediated by the tumour necrosis factor (TNF), which is secreted by macrophages [21]. In addition, leptin increases the phagocytic capacity of macrophages, increases the secretion of pro-inflammatory mediators in the acute response phase and the expression of adhesion molecules. It also increases the cytotoxic capacity of NK cells and $\mathrm{IL}_{2}[10]$.

Some studies assessed the effects of leptin upon the immune response using $\mathrm{TCD}_{4}$ lymphocytes and found that leptin induces a dose dependent increase of the proliferation of $\mathrm{TCD}_{4}$ cells. Besides, it was found that the deficiency of leptin in mice is always associated with immunosuppression and thymic atrophy similar to the one observed in acute starvation. If leptin is administered to starved animals, the normal thymic functioning is restored be increasing the number of $\mathrm{T}$ cells and decreasing the thymic apoptosis rate [11]. The aim of the present research was to investigate the effects of exogenous leptin on the ratio of $\mathrm{T}$ and B lymphocytes populations in order to evaluate the theory regarding the implication of this hormone in the stimulation of the immune system.

\section{Materials and Methods}

Wistar male rats, provided by the Animal Facility of "Cantacuzino" Institute, Romania, born and raised in compliance with the SPF conditions, with optimal biological reactivity, weighing $250-300 \mathrm{~g}$, were individually housed in polisulfonate cages and maintained in constant microclimate conditions: temperature $22 \pm$ $2^{\circ} \mathrm{C}$, humidity $55 \pm 10 \%$ and ventilation: 10 - 15 air changes per hour, on a 12/12 h light/dark cycle. After 1 week of acclimation to the laboratory, the animals were used for further experimental procedures.

The study was approved by the ethics committee of the "Cantacuzino" Institute according to EU Directive $63 / 2010$ and the national regulations.

The experiment was carried out on 20 Wistar SPF male rats divided in two groups: the control group comprised 10 rats that were injected with $0.05 \mathrm{~mL}$ $\mathrm{NaCl} 0.9 \%$ s.c. for 14 consecutive days and the experimental group comprised 10 rats that were injected with $1 \mu \mathrm{g} / 100 \mathrm{~g}$ body weight leptin (Leptin from Rat, Sigma-Aldrich) s.c. for 14 consecutive days.

Blood samples were harvested through the puncture of the tail vein after 14 and 21 days post last leptin inoculation from both groups of animals. $1 \mathrm{~mL}$ blood samples were collected from each rat in order to perform lymphocyte immunophenotyping. The peripheral blood was collected on EDTA in order to avoid the coagulation.

The samples were analysed using the direct immunofluorescence technique, as previously described [13]. We used the fluorescent monoclonal antibodies to analyse the lymphocyte immunophenotyping in the experimental rats. The used monoclonal antibodies and employed experimental procedure allowed the determination of the percentage levels of the following lymphocyte populations: $\mathrm{TCD}_{3}, \mathrm{TCD}_{4}, \mathrm{TCD}_{8}$ and $\mathrm{BCD}_{45}$.

\section{Statistical analysis}

The obtained results were statistically processed; all the data were expressed as mean \pm standard deviation (SD). Statistical analysis was performed using $\mathrm{T}$ test (Student). The $\mathrm{p}$ value $<0.05$ was considered as statistically significant.

\section{Results and Discussion}

The impact of leptin on the $\mathrm{TCD}_{3}$ (helper and cytolytic/ suppressor) lymphocyte populations is presented in Figure 1. Therefore, the administered leptin determines on Wistar SPF rats an insignificant increase of $\mathrm{TCD}_{3}$ lymphocyte populations from a statistical point of view ( $p>0.05$ ), compared to the control group of rats (increase with $10.01 \%$ ), on the $14^{\text {th }}$ day after the cessation of the administration. The stimulative effect (highly significant, $\mathrm{p}<0.01$ ) of the leptin on the $\mathrm{TCD}_{3}$ lymphocyte populations appears on the $21^{\text {st }}$ day after the administration, when it was registered an increase with $47.21 \%$ of this cell population. 


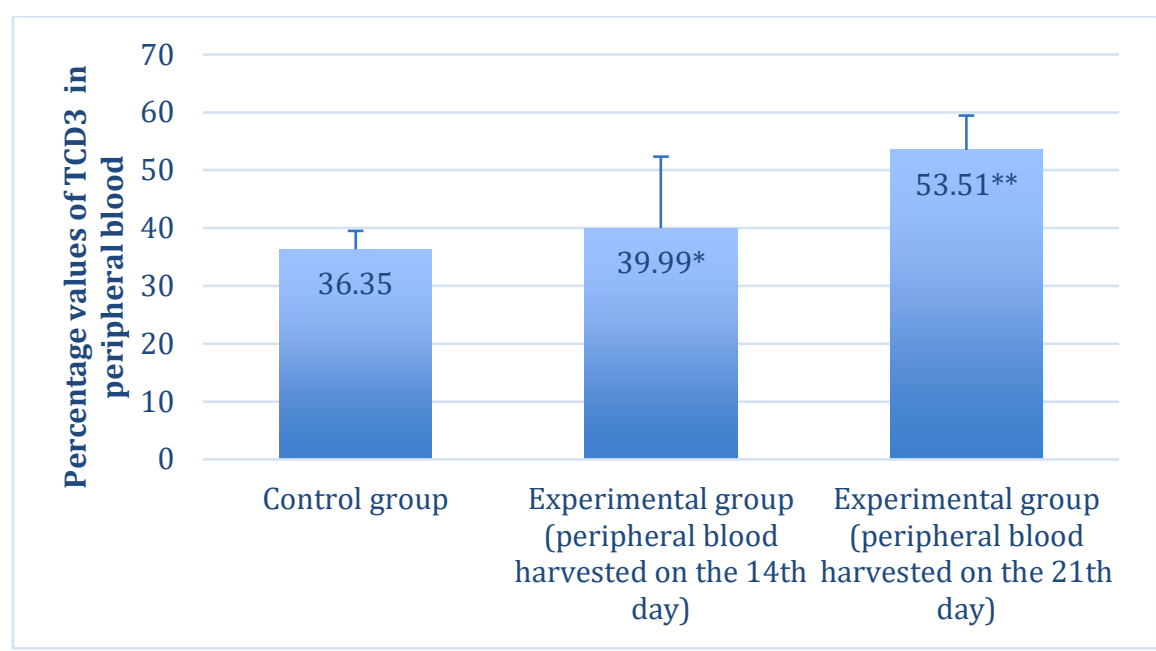

Figure 1.

Percentage values of $\mathrm{TCD}_{3}$ in peripheral blood harvested on the $14^{\text {th }}$ and $21^{\text {st }}$ day from the rats treated with leptin, compared to the control group, * $\mathrm{p}>0.05 ; * * \mathrm{p}<0.01$

Our results regarding the effect of leptin on the $\mathrm{TCD}_{4}$ (helper) lymphocyte subpopulation are shown in Figure 2. The administered leptin determined a weak effect on the experimental group, statistically insignificant ( $p>0.05$ ) compared to the control rats (an increase with $3.57 \%$ ), on the $14^{\text {th }}$ day, after the treatment. The stimulative effect of the leptin installs slowly and becomes more intense and statistically significant ( $\mathrm{p}<$ 0.01 ) on the $21^{\text {st }}$ day after the treatment, when it was observed an increase of the $\mathrm{TCD}_{4}$ cell population with $39.68 \%$.

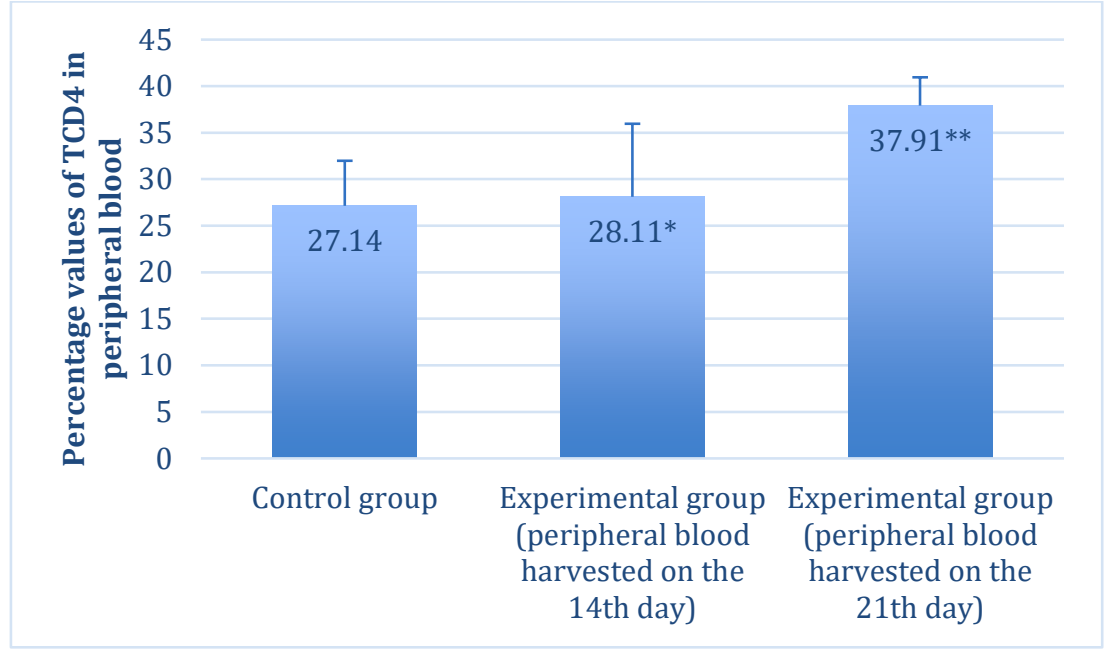

Figure 2.

Percentage values of $\mathrm{TCD}_{4}$ in peripheral blood on the $14^{\text {th }}$ and $21^{\text {st }}$ day from the rats treated with leptin, compared to the control group, * $\mathrm{p}>0.05 ; * * \mathrm{p}<0.01$

The results regarding the effect of leptin on the $\mathrm{TCD}_{8}$ (cytolytic/suppressor) lymphocyte subfamily are shown in Figure 3. The stimulative effect is weak and statistically insignificant $(\mathrm{p}>0.05) 14$ days after the last leptin inoculation (an increase of $8.10 \%$ ). However, the effect becomes intense and statistically significant $(\mathrm{p}<0.01)$ after 21 days post administration, when it was observed an increase of the $\mathrm{TCD}_{8}$ lymphocyte population with $50.43 \%$.

The results obtained regarding the effect of leptin on the $\mathrm{BCD}_{45}$ lymphocyte population are shown in Figure 4.
The incentive leptin effect is low and statistically insignificant $(\mathrm{p}>0.05)$ on the $14^{\text {th }}$ day after the treatment (an increase of $4.62 \%$ ). However, the effect becomes intense and statistical significant $(\mathrm{p}<0.01) 21$ days after the cessation of the administration of leptin, when we observed an increase of this lymphocyte population of $40.83 \%$. However, it is worth to mention that the intensity of the stimulating effect of the leptin on B lymphocytes is weaker compared to the one on $\mathrm{TCD}_{3}$ lymphocytes and the one on $\mathrm{TCD}_{4}$ lymphocytes (Table I). 


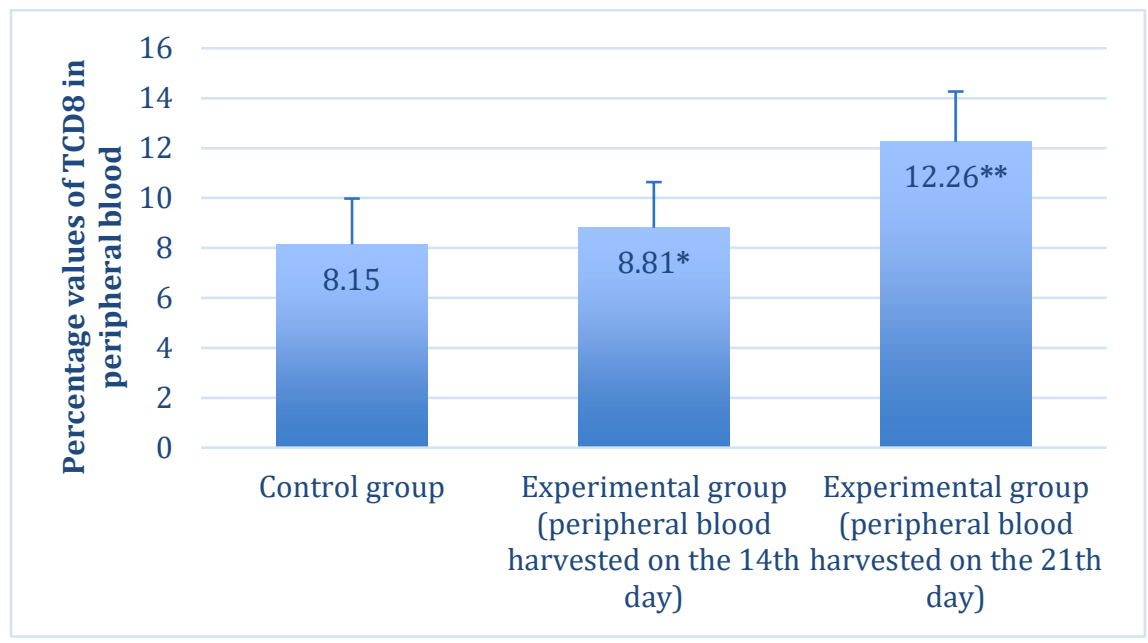

Figure 3.

Percentage values of $\mathrm{TCD}_{8}$ in peripheral blood harvested on the $14^{\text {th }}$ and $21^{\text {st }}$ day from the rats treated with leptin, compared to the control group, ${ }^{*} \mathrm{p}>0.05 ; * * \mathrm{p}<0.01$

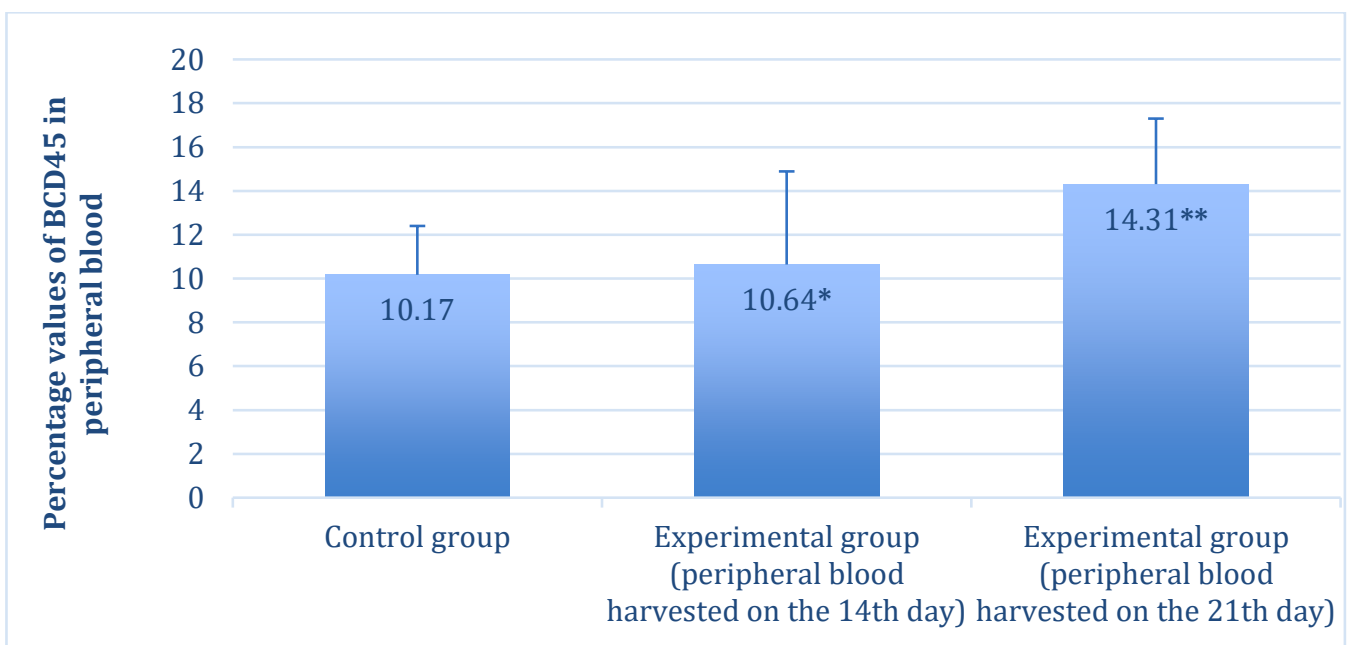

Figure 4.

Percentage values of $\mathrm{BCD}_{45}$ in peripheral blood harvested on the $14^{\text {th }}$ and $21^{\text {st }}$ day from the rats treated with leptin, compared to the control group, $* \mathrm{p}>0.05 ; * * \mathrm{p}<0.01$

Table I

Comparative percentage mean values of $\mathrm{T}$ and $\mathrm{B}$ lymphocytes after leptin and $0.9 \% \mathrm{NaCl}$ saline solution

\begin{tabular}{|c|c|c|c|c|}
\hline Group of study & $\% \mathrm{TCD}_{3}$ & $\% \mathrm{TCD}_{4}$ & $\% \mathrm{TCD}_{8}$ & $\% \mathrm{BCD}_{45}$ \\
\hline Control group & 36.35 & 27.14 & 8.15 & 10.17 \\
\hline $\begin{array}{c}\text { Experimental group } \\
\text { (peripheral blood harvested on the } 14^{\text {th }} \text { day) }\end{array}$ & 39.99 & 28.11 & 8.81 & 10.64 \\
\hline $\begin{array}{c}\text { Experimental group } \\
\text { (peripheral blood harvested on the } 21^{\text {st }} \text { day) }\end{array}$ & 53.51 & 37.91 & 12.26 & 14.31 \\
\hline
\end{tabular}

From the comparative analysis of the obtained results, it outcomes that leptin induces stimulating effects upon $\mathrm{TCD}_{4}$ and $\mathrm{TCD}_{8}$ lymphocytes subpopulations and upon $\mathrm{BCD}_{45}$ lymphocytes. This stimulative effect of leptin is more intense after 21 days from the last leptin administration, suggesting a "lag" of the activation of the lymphocytes, due to leptin.
Our results also suggest a certain receptivity of different lymphocytes' families toward the action of leptin, meaning that $\mathrm{T}$ lymphocytes and these population's subfamilies respond more intensely to the action of leptin compared to the population of B lymphocytes. Our results are in accordance with those presented by Fujita Y. et al. [5]. They studied the lymphocytes' receptors for leptin and observed that leptin induces 
the increase of longevity of lymphocytes by inhibition of their apoptosis. In addition, our results confirm indirectly the experimental data obtained by Papathanassoglou E et al. [16]. Thus, they found that leptin can counter the lymphopenic effect induced by the glucocorticoids (hydrocortisone).

Furthermore, Papathanassoglou E et al. found that the number of lymphocytes decline dramatically in the rats subjected to 60 hours of food restriction. This effect can be prevented by administering leptin. Besides, administering leptin to starving rats has led to an increase of lymphocytes' number proportional to the dose of leptin [16].

\section{Conclusions}

On the $14^{\text {th }}$ day after the last administration, leptin exhibited a stimulatory effect, insignificant from a statistical point of view upon $\mathrm{TCD}_{3}, \mathrm{TCD}_{4}, \mathrm{TCD}_{4}$ and $\mathrm{BCD}_{45}$ lymphocytes. On the $21^{\text {st }}$ day after the last administration, leptin showed an intense stimulatory effect, significant from a statistical point of view upon the following lymphocytes subpopulations: $\mathrm{TCD}_{3}, \mathrm{TCD}_{4}$, $\mathrm{TCD}_{8}$ and $\mathrm{BCD}_{45}$. Our results allow us to claim that administering leptin induces an amplification of effectors involved in the cellular mediated immune response.

\section{Conflict of interest}

The authors declare no conflict of interest.

\section{References}

1. Anghel LA, Leucuta DC, Farcas AM, Oprean RN, Utilization patterns of disease-modifying antirheumatic drugs (DMARDS) in patients with autoimmune rheumatic diseases. Farmacia, 2019; 67(1): 184-192.

2. Baskaran C, Eddy KT, Miller KK, Meenaghan E, Misra M, Lawson EA, Leptin secretory dynamics and associated disordered eating psychopathology across the weight spectrum. Eur J Endocrinol., 2016; 174(4): 503-512.

3. Claycombe K, King LE, Fraker PJ, A role for leptin in sustaining lymphopoiesis and myelopoiesis. Proceedings of the National Academy of Sciences of the United States of America, 2008; 105(6): 2017-2021.

4. Cohen S, Danzaki K, MacIver NJ, Nutritional effects on T-cell immunometabolism. Eur J Immunol., 2017; 47: 225-235.

5. Fujita Y, Murakami M, Ogawa Y, Masuzaki H, Tanaka M, Ozaki S, Nakao K, Mimori T, Leptin inhibits stress-induced apoptosis of T lymphocytes. Clin Exp Immunol., 2002; 128(1): 21-26.

6. Gerriets VA, Danzaki K, Kishton RJ, Eisner W, Nichols AG, Saucillo DC, Shinohara ML, MacIver NJ, Leptin directly promotes T-cell glycolytic metabolism to drive effector T-cell differentiation in a mouse model of autoimmunity. Eur J Immunol., 2016; 46(8): 19701983.

7. Grases-Pinto B, Abril-Gil M, Castell M, Perez-Cano FJ, Franch A, Enhancement of immune maturation in suckling rats by leptin and adiponectin supplementation. Sci Rep., 2019; 9(1): 1786: 1-12.

8. Howard JK, Lord GM, Matarese G, Leptin protects mice from starvation-induced lymphoid atrophy and increases thymic cellularity in ob/ob mice. J Clin Inv., 1999; 104(8): 1051-1059.

9. Hunsche C, Hernandez O, Mela V, Viveros MP, De la Fuente M, The Postnatal Leptin Surge Supports Immune Cell Function in Rats. Immunol. Invest., 2021; 14: 1-17.

10. Kelesidis T, Kelesidis I, Chou S, Mantzoros C, Narrative Review: The role of leptin in human physiology: emerging clinical applications. Annals of Internal Medicine, 2010; 152: 93-100.

11. Lord GM, Matarese G, Howard JK, Bloom SR, Lechler RI, Leptin inhibits the anti-CD3-driven proliferation of peripheral blood $\mathrm{T}$ cells but enhances the production of proinflammatory cytokines. J Leukoc Biol., 2002; 72(2): 330-338.

12. Mantzoros C, Magkos F, Brinkoetter M, Sienkiewicz E, Dardeno T, Sang-Yong K, Hamnvik R, Koniaris A, Leptin in human physiology and pathophysiology. Am J Physiol Endocrinol Metab., 2011; 301: 567-584.

13. Matutes E, Morilla R, Catovsky D, Immunophenotyping, In Dacie and Lewis Practical Haematology (Tenth Edition), Mitchell LS, Bain BJ, Bates I, Churchill Livingstone, 2006; 335-355.

14. Mohamad AM, Mitrea N, Nicolae AC, Constantinescu MZ, Drăgoi CM, Arsene AL, Barbu CG, The dynamics of adiponectin and leptin on metabolic syndrome patients and age matched healthy subjects. Farmacia, 2014; 62(3): 532-545.

15. Nurnazahiah A, Lua PL, Shahril MR, Adiponectin, Leptin and Objectively Measured Physical Activity in Adults: A Narrative Review. Malays J Med Sci., 2016; 23(6): 7-24.

16. Papathanassoglou E, El-Haschimi K, Chang Li X, Matarese G, Strom T, Mantzoro C, Leptin receptor expression and signaling in lymphocytes: kinetics during lymphocyte activation, role in lymphocyte survival, and response to high fat diet in mice. $J$ Immunol., 2006; 176(12): 7745-7752.

17. Pashova-Stoyanova L, Tolekova A, Ganeva M, Tsokeva Z, Hadzhibozheva P, Georgiev T, Nancheva K, Vitamin D effects on lipid profile and uric acid levels in the experimental model of metabolic disorders in fructose fed Wistar rats. Farmacia, 2019; 67(6): 1071-1076.

18. Procaccini C, La Rocca C, Carbone F, De Rosa V, Galgani M, Matarese G, Leptin as immune mediator: interaction between neuroendocrine and immune system. Dev Comp Immunol., 2017; 66: 120-129.

19. Wong CK, Cheung PFY, Lam CWK, Leptin-mediated cytokine release and migration of eosinophils: implications for immunopathophysiology of allergic inflammation. Eur J Immunol., 2007; 37(8): 2337-2348.

20. Wozniak SE, Gee LL, Wachtel MS, Frezza EE, Adipose tissue: the new endocrine organ? A review article. Dig Dis Sci., 2009; 54(9): 1847-1856

21. Zarkesh-Esfahani H, Pockley AG, Wu Z, Hellewell PG, Weetman AP, Ross RJM, Leptin indirectly activates human neutrophils via induction of TNF- $\alpha$. J Immunol., 2004; 172(3): 1809-1814. 